\title{
RELEER A SAMUEL RAMOS: MITO, MITOMANIA Y ANDROLATRIA
}

\author{
REREAD SAMUEL RAMOS: \\ MYTH, MYTHOMANIA AND ANDROLATRY
}

\author{
Marcos Cueva Perus ${ }^{(*)}$ \\ Universidad Nacional Autónoma de México, México D.F., México
}

\begin{abstract}
Resumen: este texto es parte de las reflexiones del filósofo mexicano Samuel Ramos para mostrar cómo, en la actualidad, en América Latina la religión se sirve del mito para crear el sentimiento de superioridad al que se refería ese autor en 1934, un sentimiento de superioridad que pretende incluso imponerse al europeo. El mito no es inocente y tiene todas las particularidades que lo vuelven apto para hacer pasar el poder del sentimiento de superioridad por algo "natural". El mito sirve mediante imágenes al poder y un procedimiento que no desconocen los medios de comunicación de hoy, que recuperan este imaginario religioso.
\end{abstract}

Palabras Clave: Ramos; Cultura latinoamericana; Mito.

Abstract: This text begins with the reflections of the Mexican philosopher, Samuel Ramos, to show how in Latin America, at present, religion and myth, serve to create a sense of superiority, that author referred to in 1934, a feeling of superiority that is even imposed to Europeans. The myth is not innocent and has all the characteristics that make it suitable for making the feeling of superiority something supposed to be "natural". The myth serves to power through images and it's a process that does know the media today when retrieving this religious imagery.

Keywords: Ramos; Latin American culture; myth.

(*) Doctor, investigador del Instituto de Investigaciones Sociales, Universidad Nacional Autónoma de México, México D.F., México.E-mail: cuevaperus@yahoo.com.mx. Recibido en: 22.10.2015, aceptado en: 29.12.2015. 


\section{INTRODUCCIÓN}

En un texto escrito en 1934, El perfil del Hombre y la cultura en México, el filósofo mexicano Samuel Ramos se inspiraba en Alfred Adler para señalar la existencia de dos tendencias en la personalidad del mexicano: la tendencia al sentimiento de inferioridad y como compensación, la tendencia a creerse superior. Ramos veía esta personalidad en distintos grupos sociales y en México en general: el país había tendido en el siglo XIX al autodenigramiento y al mismo tiempo a la imitación grandiosa de todo lo europeo. Ramos no era el único que veía esta problemática: el historiador de Coahuila, en el norte de México, Carlos Pereyra (1982), atribuía esta problemática a toda Latinoamérica. En su Breve Historia de América, citada por Ramos, afirmó Pereyra que frente a los adelantos estadounidenses en el siglo XIX los pueblos hispanoamericanos empezaron a experimentar un fuerte proceso de autodenigración. Durante el régimen colonial habían tenido actividad autónoma suficiente para capacitarlos y, abandonando a la riqueza ancestral que habían heredado y a la valiosa experiencia secular, pasaron a dedicarse a la imitación de la obra norteamericana. Lo de afuera fue en cambio deificado. El historiador hablaba de "deificación" de algo humano y terrenal: "[...] el criollo, afirmaba, alimentaba sus anhelos con quimeras [...] Lo que le faltó [...] fue una corriente de intereses materiales que arrastrara el exceso de idealismo implicado. Falto de fines y, por lo tanto, de orientación, el criollo la buscó en el extranjero[...]" (PEREYRA 1982, p. 371). Es probable que entre el siglo XIX y principios del siglo XX las dos tendencias aparecieran como artificiales; después tal vez se condensaron de alguna manera distinta. Es esta nueva condensación surgida en el siglo XX la que nos ha interesado aquí.

Ramos sugería que parte de la compensación daba en una ambición desmedida de poder. No hemos querido centrarnos únicamente en la "grandeza" que por lo demás muchos pequeños países de la región no tuvieron: sería difícil detectarla donde no hubo pretensiones imperiales en el siglo XIX (como si las hubo en cambio desde el México de Agustín de Iturbide hasta el tardío imperio portugués de Brasil) y en países como El Salvador (el poeta Roque Dalton lo retrató de muy otra manera en sus Historias prohibidas de pulgarcito), Costa Rica, Uruguay, Bolivia o Ecuador, por mencionar algunos. Aunque siempre con excepciones, es difícil encontrar con todo algún país que no haya tendido a fabular sobre su origen moderno: Venezuela con sus muchos "Bolívar", Costa Rica con la democracia, Uruguay con "la Suiza de América" o incluso Haití, un poco más hacia atrás, con la historia del "primer país en independizarse en América Latina". Cuando hablamos de este origen - colonial, prehispánico, independiente, moderno, revolucionario o incluso dictatorial, como ocurrió en Chile -, tocamos ya otro tipo de grandeza: la del mito. Aquí hemos querido describir a la vez formas colectivas e individuales de esta mitomanía. Hemos demostrado que la mitomanía sirvió en su forma más reciente en el siglo XX para naturalizar el sentimiento de superioridad e incluso para volverlo contra el europeo al que en el siglo XIX se aspiraba en cambio a imitar.

\section{LA MITOMANÍA EN RAMOS}

El filólogo español Carlos García Gual define al mito de un modo que no pareciera alejado de un cierto" macondismo": en estas "historias de la tribu", 
[...] el dramatismo de los mitos los caracteriza con una alegre y feroz espontaneidad. En el ámbito narrativo desfilan fulgurantes actores y allí se cumplen las acciones más extraordinarias; creación y destrucción de mundos, aparición de dioses y héroes, terribles encuentros con los monstruos etc.; todo es posible en el coloreado y mágico mundo del mito. Este carácter dramático caracteriza a estos relatos frente a las tramas verosímiles de otras narraciones, o frente al esquema abstracto de las explicaciones lógicas. El mito explica e ilustra el mundo mediante la narración de sucesos maravillosos y ejemplares[...]" (GARCIA GUAL, 2004, p. 18).

Nos ha interesado sobremanera el efecto práctico de esta mitomanía en la mentalidad de base que busca explorar Ramos: es un "efecto" que hace pasar como natural lo que no forzosamente lo es, justamente porque la mitomanía es una elaboración humana. La "manía" del mito consiste ahora en oponer algo supuestamente natural como superior a la - también supuesta - artificialidad de la Razón, retratada con esta "R" mayúscula, y desde luego que al logos. La función de esta "manía del mito" aparece como algo natural y no como una imagen elaborada en espejo de la que la razón instrumental ha querido crear. Así, se le atribuyen hoy a Latinoamérica las características mismas del mito en general, como algo positivo, puesto que estaría en una naturaleza humana por mucho tiempo olvidada. Si por momentos la polémica se instala en la tensión entre naturaleza y cultura, en Latinoamérica el mito coadyuva, nótese bien, a la imposibilidad de cuestionar una cultura que se hace pasar por naturaleza. La cultura pareciera brotar de la naturaleza sin ser un "producto", algo fabricado por el Hombre y por lo que éste tuviera que responder - el Hombre es "hablado" por estas naturalezas. Tal vez se confunden en realidad tradiciones que de todos modos tienen un origen en la sociedad - mientras que la cultura que de todos modos no se reivindica demasiado, algo que Ramos ya había hecho notar (RAMOS, 2001).

Ramos dejaba muy claro desde 1934 que no se refería en el "mexicano" a una raza y que, por lo demás, en descripciones como la del "pelado" se trata ya de un individuo de la época actual; el mexicano se siente inferior, pero no "es" inferior. Si bien el sentimiento de inferioridad es vivido, más si una sociedad se basa con facilidad en la humillación, la vanagloria carece de experiencia: tan es así que con tal de hacer algo "en grande", de lo extranjero no se entiende la propiedad o cualidad, sino que se lo imita, con actitud mimética. El asunto no es de cualidades o propiedades de las cosas sino de imágenes; lo que se percibe del extranjero es apenas una imagen. Lo mismo sucede con la percepción de lo propio, si el mexicano se ve a sí mismo como inferior, pero no lo es. Buscaremos mostrar la otra cara de esta mirada en espejo: la del latinoamericano superior al europeo también en una imagen en espejo. Esta imagen aparece así en realidad como tan natural como "lo latinoamericano" y superior - aunque suele no aplicársele al estadounidense. La incapacidad para pensar con conceptos, la facilidad para percibir con el pathos de la emoción por delante y la sustitución de cualquier potencial concepto por la imagen y por la emoción que suscita han sido lo propio de las "almas primitivas", según Lucien Lévy-Bruhl (1985), por polémica que haya sido esta afirmación incluso para este mismo autor. Es también algo de lo más frecuente en los medios de comunicación masiva actuales. 


\section{UN LATINO MUY AUTÉNTICO: IMAGEN DEL SENTIMIENTO, SENTIMIENTO DE LA IMAGEN}

En la imagen que el "latino" "vende" en ocasiones al exterior está desde luego el estereotipo del clima, de lo "caliente" contra "lo frío", aunque a veces no tenga demasiado que ver con la realidad (Arizona puede ser caliente como Sicilia y Quito frío), pero va más allá: se reivindica el sentimiento - e incluso la pasión, esa que reclamaba por ejemplo Collor de Melo ("rojo de pasión por Brasil") - contra la razón, en la reproducción de la dualidad entre el "cuerpo" y la "mente". Esta dualidad puede parecer tanto más extraña cuanto que en realidad se limita a cuerpo y "mente" y no al espíritu, por lo que no rechaza la creencia: en nombre del sentimiento, más de un latinoamericano se fiará de cualquier espíritu, será supersticioso, practicará hechicería, magia negra, vudú o santería y esperará el milagro de la Virgen (la de Guadalupe, la Aparecida y muchas otras más). Para quien crea que esto es un sincretismo que se lo debe todo a lo subalterno, Ludwig Schajowicz, un peculiar autor austríaco que vivió desde finales de los años 30 en el Caribe (Cuba y Puerto Rico) recuerda lo que eran los españoles del siglo XVII, apegados a una religión exuberante en sus exageraciones, que no eran todas las de la Inquisición:

En la España del siglo XVII la cosmovisión cristiana seguía teniendo vigencia como fuerza moderadora de la conciencia de todas sus capas sociales. Aunque el empuje creador de la Contrarreforma se debilitaba gradualmente en las artes y las letras, su ideología religiosa, protectora de un orden jerárquico establecido, permanecía intacta, formando un dique contra la infiltración de las corrientes racionalistas o liberales [...], principalmente en Francia e Inglaterra. Impedía, además, su difusión en España el sentido de lo maravilloso, fuertemente arraigado en el pueblo entero, su fe en los milagros, su honda receptividad para leyendas e interpretaciones poéticas de lo sobrenatural, al par que el cúmulo de supersticiones, factores que facilitaban la pervivencia de formas de vida apenas compatibles con el nuevo ethos de la libertad de un Descartes o de un Locke (SCHAJOWICZ, 1990, p. 332).

El mito se define para muchos autores como una forma de acceso a un "mundo" u "otra realidad" ajena a la razón. Esta "verdadera vida" comienza por la naturaleza que en Latinoamérica es mostrada como inmensa y sobre todo abundante, pródiga, hasta hoy con espacios vírgenes e incluso con "tribus no contactadas", sin "la mano del Hombre". Esta visión de un mundo "pródigo por naturaleza" - supuestamente pródigo en el paisaje y en su "Humanidad" - no se basa en el trabajo y es semejante al que describe Jean-Pierre Vernant al tratar de los mitos en la Grecia antigua, según veremos. Hay en realidad de todo menos de inocencia, pese a esta afirmación: "[...]el relato mítico tiene funciones catárquicas en cuanto restituye al hombre la inocencia de su visión. Delante de sus ojos maravillados comienzan las cosas a fulgurar de nuevo, como el primer día del universo re-creado por la palabra [...]" (SCHAJOWICZ, 1990, p. 23).

El predominio otorgado a la imagen lo es también para lo sensorial, por lo que no falta el "latino sensual" - el estilo frecuente era hasta hace poco Sonia Braga - "Tieta" o "Gabriela" -. La naturaleza colma los sentidos. Para Schajowicz, 
Concebir el alma como espejo de imágenes equivale a decir que la retención misma de impresiones sensoriales, y su integración a unidades de sentido más complejas, es constitutiva de la vida anímica superior. Tal vez convenga, prosigue este autor, representarse esta relación descomponiéndola en dos movimientos complementarios: el alma se 'imagina' las cosas o, lo que es igual, las des-cubre y las in-forma a sí misma, mientras que las cosas acuden al alma para reflejarse en ella" (SCHAJOWICZ, 1990, p. 24).

Ciertamente, el mexicano se imagina en el sentimiento de superioridad lo que quiere ser, del mismo modo que el nacional se imagina en la deificación de lo extranjero qué es, aunque no se sale de la imagen. Para Schajowicz no hay rodeos: "[...] el alma no puede vivir sin imágenes so pena de dejar de ser - alma [...]" (SCHAJOWICZ, 1990, p. 27). El alma no admite mayor explicación porque no la hay para las imágenes, que se "revelan": "[...] el impacto de lo divino en nuestro interior o la fuerza de irradiación de las imágenes míticas que lo han moldeado, no son algo objetivable con el fin de una explicación analítica [...]" (SCHAJOWICZ, 1990, p. 27). Queda el éxtasis "[...] si las 'cosas' son figuras divinas cabe frente a ellas una sola actitud, la que Schopenhauer nos recomienda para entrar en contacto con obras de arte, que él compara con aquellos grandes señores en cuya presencia debemos esperar pacientemente que nos dirijan la palabra [...]" (SCHAJOWICZ, 1990, p. 30).

Esta visión que privilegia a la imagen se encuentra también en estudios antropológicos como los de Claude Lévi-Strauss, tal vez no disociada de las posibilidades que le puede abrir a la cibernética a partir de la lingüística estructuralista. El antropólogo Lluis Duch toma en consideración una interpretación de Giovanni Reale, para quien del mundo físico no se puede tener el ser puro, sino exclusivamente su imagen, por lo que no se pueden aplicar razonamientos verdaderos, sino apenas verosímiles: es así que el ser humano puede darse por satisfecho con el mito como "narración probable" (DUCH 2002, p. 74). En Lévi-Strauss pareciera mantenerse cierta ambigüedad, puesto que se refiere a "imágenes extraídas de la experiencia" (2012, p. 47), pero señala: "[...] la originalidad del pensamiento mitológico (consiste) en desempeñar el papel del pensamiento conceptual [...]", de tal modo que el pez de un mito canadiense procede como un "operador binario" ("sí", "no"), algo que impediría oponer tajantemente mito y ciencia (LEVI-STRAUSS, 2012, p. 47-48). Estaríamos ante una reivindicación del más primitivo de los mitos en un mundo donde el interés de los medios de comunicación masiva, que proceden con imágenes sin mostrar nunca el "concepto", está también en mover a la emoción para entrar en "otra realidad". En ciertas reivindicaciones del mito, este llamado a "suscitar la emoción" apela además a la sacralización mediante el recurso - no ajeno a la religión - a lo "enigmático" o "misterioso" del "alma humana" frente a las pretensiones de la razón instrumental.

Para muchos simplemente se trataría entre el mito y la razón de dos formas distintas de captación de una misma realidad, aunque alguien como Lévi-Strauss llegó a plantear el entrecruzamiento de esas mismas formas, a diferencia por ejemplo de Maurice Leenhart. Con todo, el mito pretende ser "expresivo" frente a la creciente inexpresividad del mundo actual. El latinoamericano abraza, gesticula, parece espontáneo, es arrojado. El mito es el "lado afectivo" que se expresa, espontáneamente además. Lo que sostiene Leenhart es que "[...] el mito corresponde a un modo de conocimiento afectivo, paralelo a nuestro modo de conocimiento objetivo, desarrollado por el método[...]" (LEENHART, 1997, 
p. 186). Así por ejemplo, “[...] el mito melanesio es vivido antes de ser formulado, fijado en una mitología y revivido por un ritual [...]" (LEENHART, 1997, p.184). Primum vivere [...] Así, "[...] el mito es sentido y vivido antes de ser inteligido y formulado. Son la palabra, el rostro, el gesto que circunscriben el acontecimiento en el corazón del hombre, emotivo como un niño, antes de ser relato fijado[...]" (LEENHART, 1997, p. 184). El "latino" tiene entonces una naturaleza que privilegia la emoción.

En algún momento la reivindicación de esta primacía afectiva del mito le correspondió al romanticismo, en particular alemán. "Para los pensadores románticos el retorno a las fuentes míticas libera el sentimiento y la imaginación, que habían sido fuertemente reprimidos por una reflexión filosófica basada primordialmente en la cuantificación y en la verificación [...]" (DUCH, 2002, p. 127). En efecto, el romanticismo aspira a "revitalizar" todo lo que la Ilustración - frecuentemente confundida en el pensamiento alemán con el cálculo - pareciera haber congelado. El filósofo alemán Hans-Georg Gadamer ha puesto este énfasis en un romanticismo que impide cualquier fisura, puesto que el sentimiento calla al argumento, al remontarse aquél a un origen fuera de discusión. Gadamer explica al mito como una especie de "acta notarial" y al mismo tiempo como una forma de narrar cuyo propósito, lejos de cualquier argumentación, es cautivar al oyente, como se puede quedar cautivo ante cualquier exotismo que se desconoce o incluso, agreguemos, ante el "macondismo" o una supuesta lluvia de peces en la localidad hondureña de Yoro-Yoro. Para Gadamer, quien intenta a su modo cierta conciliación entre mito y razón, “[...] 'mito' no designa otra cosa que una especie de acta notarial. El mito es lo dicho, la leyenda, pero de modo que lo dicho en esa leyenda no admite ninguna otra posibilidad de ser experimentado que justo la de recibir lo dicho [...]" (GADAMER, 1997, p. 17) - como en la contemplación de Schopenhauer ante el señor magnánime. En efecto, "[...]el narrador presupone que el otro desea oír cosas. Este ha dejado clara, por así decir, de partida su disposición y su estar abierto al mensaje. Caerá cautivo, si uno sabe contar [...]" (GADAMER, 1997, p. 33). ¿Qué "impacta" en el mito? Que "[...] ante la significación de lo narrado queda acallada la pregunta por la autenticidad y la fiabilidad del informe [...]", según Gadamer (p. 35). Lo verosímil basta para dar fe de la autenticidad. Así,

Aquello sobre lo que se narra alcanza en la narración una suerte de reconocimiento que está por encima de cualquier informe detallado que se pueda hacer al respecto [...] Lo que importa en este caso no es la creencia, sino el reconocimiento y la presentación conmemorativa de una certeza sobrecogedora (GADAMER, 1997, p. 35).

Denis de Rougemont, filósofo suizo, lo dice a su manera y no está de más recordar la tendencia en México y en Latinoamérica a mitificar la familia - en una comunión de base biológica, a partir de la figura de la madre - reconciliándola por sobre cualquier fisura, sobre todo en la telenovela más tradicional:

La oscuridad del mito en general no reside en su forma de expresión. Está relacionada, por un lado, con el misterio de su origen y, por otro, con la importancia vital de los hechos que el mito simboliza. Si estos hechos no fueran oscuros, o si no se tuviera un interés en oscurecer su origen y su alcance para sustraerlos a la crítica, no hubiera necesidad del mito (ROUGEMONT, 2001, p. 20). 
Así que ante el sentimiento no habría más que callar cautivo.

Al expresarse, el mito calla porque no admite ningún debate "racional"; no necesita de argumentación. Para el filósofo Hans Blumenberg:

"[...] en la recepción de la tradición mítica [...] está en juego algo de (la) transferencia de afectos a lo primitivo que retorna. La movilización de los afectos se vuelve relevante para el enunciado así enfatizado, cobra una importancia que parece no necesita una argumentación ulterior [...]" (BLUMENBERG, 2004, p. 39).

No parece haber mucha manera de refutar la existencia de un sentimiento que se aleja de la represión y que, saliendo de donde estaba enterrado, regresa con fuerza y espontaneidad, pareciera que casi de manera gratuita (icomo el señor de Schopenhauer?): aquí no se argumenta nada. ¿Dónde está la eficacia del mito en su recepción?: en este "diálogo del alma consigo mismo", y sucede que,

Alusión y variación, rectificación y complementación, vislumbre y sorprendente desenlace son imitaciones, reproducciones de las estructura de la anamnesis fatal. La metáfora platónica de la anamnesis contiene ya una suposición relevante: que, con ocasión de impresiones externas, se imponga con vehemencia la verdad preexistentemente conocida [...]" (BLUMENBERG, 2004, p. 37).

Fuera de toda posibilidad de argumentación racional y proviniendo por lo demás de un fondo primitivo que por lo mismo difícilmente podría ser verificado, el mito termina aquí al servicio de una supuesta "naturaleza humana" que como tal se contrapone a la artificialidad de la "Razón". Lo propio de esta "naturaleza humana" es una especie de fusión originaria mediante los sentidos con la otra naturaleza - la geográfica y la emocional - y tal vez lo sea también con los "afectos" que retornan una y otra vez, repitiéndose, puesto que, según Blumenberg, la repetición es lo propio del mito:

La estructura mítica tampoco sigue el camino del rodeo - considera Blumenberg - sino el de la repetición, explícitamente, el del retorno a lo mismo, en contraposición con el progreso lineal. La estructura circular cerrada de este esquema parece ofrecer, frente a la indeterminación de una forma racional de la progresión, algo así como una certeza consoladora de la que es posible fiarse, aunque ésta sea la de la muerte (BLUMENBERG, 2004, p. 82).

Desde el punto de vista de lo dicho hasta aquí, la sociedad tampoco podría ser pensada como no sea mediante el uso del mito, un mito finalmente "armónico" en sus distintos niveles, sin fisuras y capaz en todo caso de hacerlas a un lado en nombre de la comunión con todas las naturalezas - las tradiciones parecieran ser una sociabilidad "al natural", dicho sea de paso. Aquí, finalmente, la "naturaleza humana" de primacía afectiva, frente al artificio intelectual, aparece como "lo auténtico", el equivalente del do kamo melanesio (la verdadera persona) (LEENHART, 1997). Entre esta comunión y el revestimiento de autenticidad que tiene anida el anhelo de "no caer", o de hacerlo a lo sumo en lo que Blumenberg (2004) llama "arcaica resignación".

Schajowicz también llega bastante lejos en esta aproximación a la "autenticidad" del ser mitológico (o mitologizado) y de lo siguiente se entiende que pueda sentirse im- 
buido de poder. El autor defiende que el griego no vio en los dioses un límite para sus posibilidades sino que sus posibilidades mismas. Según esta intuición, prosigue el autor,

La libertad no es algo "dado" o un "derecho" nuestro, constantemente amenazado por unos dioses caprichosos, sino que es el estado de plenitud al que ascendemos por haber adoptado la actitud de humildad ante el Ser. La figura divina no dice al griego "tú debes" - lo cual incita siempre a la insurrección del "yo quiero" - sino: ¡contémplate y llega a ser tú mismo!" (SCHAJOWICZ, 1990, p. 347).

Esta metamorfosis se logra en el contacto con lo divino, en un mirarse a sí mismo como expresión de lo divino (i), y así, "[...] sólo llego a ser un yo libre en la medida en que he renunciado a un yo trivial que parece impermeable a lo "divino[...]" (SCHAJOWICZ, 1990, p. 347). La autenticidad de la naturaleza geográfica, de la emoción y de la tradición revela con imágenes la presencia de lo divino.

¿En qué no hay tanta inocencia? En la mitología griega no hay mucho espacio para el trabajo, sin valor para Platón, a diferencia del arrojo guerrero o de la sabiduría del político. "Se puede decir que para Platón el trabajo permanece extraño a todo valor humano y que en ciertos aspectos se le muestra incluso como la antítesis de lo que en el hombre es esencial" (VERNANT, 1973, p. 249), por lo que este rechazo no es exclusivo del hidalgo español frente a las artes manuales. En efecto, Prometeo es visto con ambigüedad, puesto que le ha robado el fuego a la inmortalidad para dárselo a los hombres. De paso, no hay delimitación clara entre trabajo y técnica, sobre todo que ésta tampoco tiene mayor valor, ni moral ni psicológico. En todo caso, "[...] las actividades de oficio, limitadas a lo económico, son exteriores a la sociedad política [...]" (VERNANT, 1973, p. 266) y por cierto que también a la religión. Por así decirlo, el oficio "no trasciende". Los "demiurgos" están en el mundo de la necesidad, las políticos y guerreros en el de la capacidad, por lo que aquellos tienen una carga de "constreñimiento y servidumbre" (VERNANT, 1973, p. 272). Podría pensarse entonces que con una mitología como ésta, un sentimiento de superioridad difícilmente valoraría el trabajo y el saber técnico y preferiría el "ocio" político o la actividad del guerrero. En realidad, en la Grecia antigua y en su mitología, la riqueza no es "producida": sale de la tierra/naturaleza que es fecunda. Pandora tiene todos los dones de la tierra, aunque supone también ociosidad y dilapidación. En cuanto al cultivo de los cereales, que le toca al labrador, requiere de un ritmo religioso acorde con los dioses. Esta agricultura, conforme a la naturaleza y que por ende no se constituye en profesión se opone al muy mal visto artesanado, que en cambio es un oficio (aunque concebido como un servicio para quien hará uso del producto); lo es a diferencia de la virtud práctica en la agricultura, que no requiere de un aprendizaje especial. Finalmente, el mismo artesano se ve ceñido a una tradición y a las "habilidades prácticas" antes que a la aplicación de una ciencia, y la antigua Grecia no destaca - tampoco lo hará la España colonial - por su pensamiento técnico, del que no tiene ni siquiera un concepto preciso. "Así pues, excedido por el mismo producto que fabrica el artesano no gobierna a la naturaleza, se somete a las exigencias de la forma. No necesita, en el trabajo, ni espiritu de iniciativa ni de reflexión Su función y su virtud, dirá Aristóteles, es obedecer" (VERNANT 1973, p. 300). Para el griego antiguo, trabajar no es transformar la naturaleza ni transformarse a sí mismo. Si existe algún sentimiento de superioridad en esta Grecia antigua 
marcada por el mito, no está en el trabajo - no lo está tampoco en América en los libros del Conquistador. Por lo demás, toda la reactualización actual del mito tiene que ver con el reproche de que una "racionalidad" occidental habría terminado por desfigurar tanto al Hombre como a la naturaleza, sin que nunca quede del todo claro si por el trabajo o por la técnica, pero sí en todo caso por falta de contacto, si no con la religión, sí por lo menos con un mundo sensorial con el que se comulga por "inspiración" o por una especie de "don natural". Quien en un marco social como éste tenga sentimiento de superioridad podrá hacer creer que es por ese "don", y no debido a un trabajo reservado a otros, quienes "pasan necesidad".

En todo caso, pese a lo seductor de esta presentación sobre fondo mítico, la relación del mexicano - como la del latinoamericano en general - consigo mismo y con la naturaleza no suele estar mediada por una "acción transformadora" que incluya una técnica y el concepto de la misma.

Con la más superficial inspección de nuestro contorno social observaremos que la vida mexicana, en todas partes, se ha orientado a la consecución de resultados inmediatos. Los programas de la vida individual o social están calculados para el presente, o para el futuro más próximo. Poco importa que la realidad no responda satisfactoriamente a esta impaciencia del afán humano: al menos, la intención es ésa. Esta vida hace la impresión de una actividad irreflexiva, sin ninguna finalidad precisa, con todos los caracteres de la conducta instintiva" (RAMOS, 2001, p. 84).

Así parezca fuerte, "[...] el mexicano considera que las ideas no tienen sentido y las llama despectivamente "teorías"; juzga inútil el conocimiento de principios científicos. Parece estar muy seguro de su sentido práctico. Pero como hombre de acción es torpe, y al fin no da mucho crédito a la eficacia de los hechos [...]" (RAMOS, 2001, p. 59). El resultado ha sido incluso cierto vacío cultural: "[...] la cultura en México ha tendido siempre al aprendizaje de resultados, de verdades hechas, sin reproducir el proceso viviente que ha conducido a esas verdades. Por eso la cultura no ha sido efectiva como agente de promoción del espiritu, es decir, no ha sido 'humanista'[...]" (RAMOS, 2001, p. 102). Lo que prevalece es el desajuste psíquico que por tensión puede dar la impresión de vida, pero que es "eterno" y no evoluciona porque en el mito el Hombre "es", y no transforma a la naturaleza ni se transforma a sí mismo:

El individuo afectado por el complejo de inferioridad, al decir de Ramos, es un inadaptado a su mundo, porque existe una inadaptación dentro de sí mismo, un desajuste de sus funciones psíquicas que desequilibran la conciencia. Es por lo general un individuo cuyas ambiciones son desproporcionadas a sus capacidades; hay un déficit del poder respecto del querer [...]. Pero se comprende entonces que la inferioridad no es real, sino únicamente relativa a lo desmesurado de la ambición. Si ajustamos nuestro querer a nuestro poder, entonces el sentimiento de inferioridad no tiene por qué existir (RAMOS, 2001, p. 113).

Esta conducta que niega la necesidad y opta por la superioridad - en el ambiente y en la emoción - "es" y "se manifiesta", sin transformarse, a falta de trabajo; la otra suele ser rechazada por "artificial": improvisar es natural porque es ser espontáneo, prever cualquier cosa es plantear una transformación que pareciera incluso alterar una natura- 
leza. Este instinto es así confundido con la naturaleza humana y el "pelado" de Ramos afirma: "[...] un europeo, tiene la ciencia, el arte, la técnica etc, etc.; aquí no tenemos nada de esto, pero... somos muy hombres[...]" (RAMOS, 2001, p. 56).

\section{LA ANDROLATRÍA COMO MITIFICACIÓN}

Ramos le atribuía solamente a quien llamaba "burgués mexicano" el hecho de querer refrendar mediante otros una imagen de sí mismo que implicara un sentimiento de superioridad. Para Ramos, hay autoengaño: "[...] como el autoengaño consiste en creer que ya se es lo que se quisiera ser, en cuanto el mexicano queda satisfecho de su imagen, abandona el esfuerzo en pro de su mejoramiento efectivo[...]" (RAMOS, 2001, p. 64). Satisfecha la identidad con la imagen, la mínima acción transformadora se detiene, cuando la hubo. Según Ramos, "[...]podemos representarnos al mexicano como un hombre que huye de sí mismo para refugiarse en un mundo ficticio[...]" (RAMOS, 2001, p. 65), en el que se detiene. Ramos sugiere que se pierde así el "conócete a ti mismo" (RAMOS, 2001, p. 65), pero tal vez esto ocurre porque el sentimiento de superioridad aparece como algo natural por alcanzar e incluso como una naturaleza eterna, puesto que es algo mítico y religioso. Para que suceda así ha sido necesario que el poder se naturalice. En el apartado anterior hablamos de una especie de mito latente, cuyo origen estaría en algo así como un Paraíso del que ni Adán ni Eva fueron expulsados jamás. Ahora mostramos en este apartado las dimensiones a la vez colectivas e individuales de este "mito latente".

El psicoanalista alemán Alfred Adler no disocia en El sentido de la vida esa descripción de la superioridad de la del niño mimado, engreído y con muchos otros defectos que describe la Psicología Individual del autor mencionado.

El aire pretencioso, la vanidad en cuanto al porte exterior, por elegante o descuidado que éste sea, puede llamar la atención sobre un complejo de superioridad fácil de descubrir, así como toda una serie de fenómenos de diverso orden, como la extravagancia en el vestir, la adopción de una actitud exageradamente varonil en las mujeres o afeminada en los hombres, el orgullo, el sentimentalismo exagerado, el esnobismo, la jactancia, el carácter tiránico o descontentadizo, la tendencia a desestimarlo todo (descrita por mí como particularmente característica), el culto exagerado a los héroes, el afán (de) relacionarse con personalidades destacadas o [...] dominar sobre débiles, enfermos o personas de poca monta, la aspiración exagerada a la originalidad, abuso de ideas y corrientes ideológicas en sí valiosas con miras a desvalorizar al prójimo etc. (ADLER, 1956, p. 105).

Esta es la forma primigenia que asume el poder en el sentimiento descrito, que aparece caracterizado "[...]por la propia atribución de dotes y cualidades sobrehumanas [...]" (ADLER, 1956, p. 104). Para Ramos,

En donde hay un sentimiento de inferioridad surge la ambición desmedida de poder, que quiere decir la primacía de un mundo en que todas las cosas son vistas bajo la óptica de lo superior y lo inferior [...]. La lucha por el poder en todas sus esferas, grandes o pequeñas, en lo privado o en lo público, en el círculo familiar o nacional, conduce frecuentemente al aislamiento, la misantropía, las neurosis...etc., etc. Todos estos efectos traducen la inadaptación a la vida de la comunidad [...]" (RAMOS, 2001, p. 113). 
El paso se da gradualmente, según el filósofo mexicano:

La operación consiste, en su forma más simple, en superponer a lo que se es la imagen de lo que se quisiera ser, y dar este deseo por un hecho. Unas veces, su deseo se limita a evitar el deprecio o la humillación, y después, en escala ascendente, encontraríamos el deseo de valer tanto como los demás, el predominar entre ellos, y por último, la voluntad de poderío (RAMOS, 2001, p. 63).

Lo que sostenemos es que este afán no se presenta y no es vivido como tal, sino como una especie de comunión con cualidades sobrehumanas que suelen verse inscritas, si no en la cultura, sí al menos en tradiciones religiosas. Adler consideraba que no es raro que el individuo con sentimiento de superioridad crea en poderes sobrenaturales, aunque no hay mención ninguna del mito: "[...]la credulidad, la fe en aptitudes telepáticas o semejantes, en aptitudes proféticas, despiertan asimismo la justificada sospecha de un complejo de superioridad [...]" (ADLER, 1956, p. 105). En todo caso, partiendo de la explicación de Vernant referida en el apartado anterior, no sería de descartar que quien crea ser superior tenga al mismo tiempo la idea de que la comunidad está dada, a disposición, también en forma "natural" - más si no se ve el trabajo creador.

Esta "naturaleza humana" que comulga, que es "parte del paisaje" (paradisíaco) y que en sus sentimientos es auténtica puede ser la que arrope el sentimiento de superioridad. Para decirlo de otro modo, el sentimiento de superioridad que compensa al de inferioridad no se presenta como tal, sino que lo hace con la revestidura mítica que al mismo tiempo lo hace parecer natural, parte de una tradición "ancestral" y por lo demás irrebatible, puesto que aparece como "lo evidente": dicho en términos religiosos, es en el país periférico donde los habitantes tienen "alma" y "agasajan", mientras ésta hace falta en el "frío" del "racionalismo" o del "cartesianismo". Schajowicz lo reivindica como el mundo que tiene "espíritu" y que está por encima de "lo cotidiano":

El espíritu, dice este autor, trata de liberarse de la rutina de sus interpretaciones de la realidad histórica para recuperar las veneraciones originarias, fundamentales de la existencia [...]. Vivir poéticamente no es huir al reino de las ilusiones sino que significa tener el valor de defender las imágenes de lo divino y lo humano, en virtud de las cuales nuestra vida se espiritualiza (SCHAJOWICZ, 1990, p. 37).

Así, " [...] la vida sin mythos se torna insípida porque carece de incitaciones para la auténtica re-creación del espíritu [...]" (SCHAJOWICZ, 1990, p. 38). Y frente a la sensualidad y el alma latinos, cualquier europeo es "insípido" ¿e inferior o al menos "mal dotado por la naturaleza"?

Quien tiene el sentimiento de superioridad puede creer que a través de este poder hablan lo divino y el mito, diáfano, dúctil, que "[...] en su perfección coincide con aquella época en que los cantores no eran ya únicamente los portavoces del espíritu de la comunidad, sino que recibían la revelación divina en calidad de individuos [...]", según Walter F. Otto, filólogo alemán que escribe entre finales de los años 20 y principios de los 30 - el primer gran trabajo de este autor apareció en 1929 (OTTO, 1997, p. 25). Otto afirma sobre los hombres: “¿Qué mejor alternativa, al tener realmente a los dioses ante ellos, que convertirse ellos mismos en monumentos vivos de su ser?" (OTTO, 1997, p. 23). Ramos había encontrado una expre- 
sión acabada de este fenómeno en el mexicano acomodado: refiriéndose a este "burgués", señalaba que "[...] el 'yo' ficticio construido por cada individuo es una obra tan acabada y con tal apariencia de realidad, que es casi imposible distinguirla del 'yo' verdadero [...]" (RAMOS, 2001, p. 63). Hay ciertamente algo peculiar en quien, ya hecho todo un mitómano, "[...] consciente de su carácter ficticio, parece también sacar placer al desempeñar un papel, al meterse en el personaje o en la acción que inventa [...]" (DORON et PAROT, 2008, p. 370). Puede ser a la vez el atractivo de la grandeza sobre la que da vueltas insistentemente Otto, o también el hecho de que "[...]el sujeto, con la intención de captar la atención del otro, de seducirle y deslumbrarle, se deja llevar por fabulaciones mentirosas colocándole en general en una situación ventajosa[...]" (DORON et PAROT, 2008, p. 370). A mayor grandeza, ciertamente, mayor desventaja del otro. Basta con lo que aún con una imagen de por medio "se hace patente por sí mismo", según Heidegger (apud SCHAJOWICZ, 1990, p. 24). Schajowicz ha estudiado los lazos de éste y otros pensadores alemanes con esa Grecia antigua llena de mitologías ante las cuales se estrellaría lo que para Heidegger era la "razón esterilizante", y a la que sería de preferir "la sabiduría del amor"...en vez del amor a la sabiduría (SCHAJOWICZ, 1990).

Para Ramos, la religión es la clave de la cultura mexicana:

"[...]el motivo vital, que al coordinar nuestra actividad psíquica desde la Conquista, le da categoría de cultura, es la religiosidad [...] Por cualquier lado que se tome nuestra ascendencia, por la del indio o del conquistador español, desembocamos en razas de una religiosidad exaltada[...]" (RAMOS, 2001, p. 69).

Según Emile Durkheim, uno de los fundadores de la sociología, quien profesa una religión se siente con algo especial: la fe. Los creyentes

[...] sienten, en efecto, que la verdadera función de la religión no es hacernos pensar, enriquecer nuestro conocimiento, agregar a las representaciones que debemos a la ciencia representaciones de otro origen y de otro carácter, sino hacernos actuar, ayudarnos a vivir. El fiel que ha comulgado con su dios no es solamente un hombre que ve verdades nuevas que el no-creyente ignora; es un hombre que puede más. Siente en sí más fuerza para soportar las dificultades de la existencia o para vencerlas. Está como elevado por encima de las miserias humanas porque se ha elevado por encima de su condición de hombre; se cree salvado del mal, cualquiera que sea la forma, por otra parte, en que conciba el mal. El primer artículo de toda fe es la creencia en la salvación por la fe[...]" (DURKHEIM, 2000, p. 428).

Es hoy el "natural" el que llama al "racional" a salvarse por la fe y no por la Razón o por la ciencia: no deja de ser éste un pedido de credulidad. Esa representación para "ayudar a vivir" es la que "puede más", por lo se ha asociado aquí "la vida misma" y el poder de la misma manera - aunque tal vez más generalizada - que otro puede asociar ciencia y poder o más aún, técnica y poder - ¡cada quien lo suyo! El sentimiento de superioridad "vital" que puede ser incluso gozado u ostentado no aparece así como patología (es significativa al respecto la expresión "esto sí es vida" de quien "ya la hizo", distinta por cierto del tranquilo "pura vida" costarricense). En la religión y más aún en la mitomanía, elevarse por encima de estas miserias, nótese bien, es elevarse por encima de la condición de Hombre, volverse sobrehumano: este es el punto donde interviene 
el mito que vela la posibilidad de que "sobrehumano" sea también "inhumano", al menos según lo veían Ramos y Adler. La misma religión, ayudada por el mito, hace que tal o cual persona crea tener un poder "sobrenatural", por encima del "natural de los hombres"; se trata a escala individual de esa deificación colectiva a la que alguna vez se refiriera Carlos Pereyra y que supone de los demás que refrenden ese poder, puede ser que con idolatría o con veneración. Es así que el colectivo se encuentra llamado a practicar la androlatría que criticaba alguna vez Octavio Paz (1990, p. 156). Como se trata de superioridad, puede suponerse el menosprecio por quien ha quedado en estado de necesidad (el equivalente del artesano griego), salvo que haya en la miseria abundancia de "almas inocentes".

Ese elevarse por encima de la condición de Hombre - y ser eventualmente deificado, objeto de culto por ser un mito - no es otra cosa que el anhelo religioso de "trascender".

Por su inmersión en la vida profana tiende el hombre a "olvidar" su intuición de la vida natural y ha de ser reconducido, entonces a las realidades míticas mediante una periódica sacralización de su existencia. La re-presentación del mythos en el acto cultual restituye al participante un horizonte dentro del cual hasta sus actos más profanos cobran sentido por tener su paradigma en la "eternidad". Atribuir carácter sagrado a las proto-situaciones míticas es conferirles de antemano la autoridad que requieren para hacernos transparentes nuestras propias experiencias (SCHAJOWICZ, 1990, p. 61).

Hay así en cierto modo una "reconducción" del Hombre hacia el mundo al mismo tiempo natural y sagrado, si todo lo natural es sagrado. Quien ha sido reconducido puede ser quien ha "trascendido". Schajowicz busca ir más allá de toda determinación, contra el filósofo español Ortega y Gasset: "[...] si nuestra adoración es la fuente de nuestra vida espiritual, hemos de reconocer que su núcleo más íntimo no está sujeto a los determinismos sociales [...]" (SCHAJOWICZ, 1990, p.33). Afirma igualmente Schajowicz: "[...] conviene recordar que existen constelaciones que podrían aconsejarnos la siguiente modificación de la fórmula orteguiana: si no me salvo de mi circunstancia he de hundirme, puesto que, a la larga, mi circunstancia me 'tragará[...]" (SCHAJOWICZ, 1990, p.36). Ya se ha producido el mismo fenómeno descrito por Vernant para la Grecia antigua.

Ramos parecía considerar que el individualismo - de origen español - que acompañaba al sentimiento de superioridad debilitaba a la comunidad. Sin embargo, bien puede existir la creencia en la comunión con una sociedad que dice a partir de cierto momento tener "alma", en una fusión primitiva y que se explica también porque el poder se obtiene de la comunidad misma: sucede como el niño que al decir de Lévy-Bruhl,

No se aprehende todavía más que como un ser u objeto semejante a aquellos que lo rodean. Sólo habla de sí mismo en tercera persona. Ha adoptado con toda naturalidad, junto con el lenguaje de las personas que le entienden, la representación que éstas se hacen de él. Pasan años hasta que dice "yo" (LÉVY-BRUHL, 1985, p. 12).

Esa representación es la imagen que le devuelven de él; en el sentimiento de superioridad, quien lo tiene se dirige precisamente a la imagen y a su reflejo en el otro, sobre 
todo si es la del poder, por lo que en vez de un "yo" hay efectivamente un "mito que habla" - el colmo puede estar en el "prócer" que hace enterrar su propia pierna, como lo hiciera Santa Anna en México en el siglo XIX, por ejemplo.

Para Durkheim, lo que hace a la colectividad actuar de este modo es el rito (en este caso, lo específico de la androlatría es rendirle culto a un ser humano, de carne y hueso). Para Durkheim, el mito es una parte esencial de la vida religiosa y "[... si se retira el mito de la religión, hay que retirar igualmente el rito [...]", ya que el rito es "el mito en acción [...]" (2000, p. 86). El mismo Durkheim sugiere que lo descrito surge de una necesidad social: la de idealizar, aunque se convertirá en necesidad de engrandecer, enaltecer, rendir pleitesía. Otto, estudioso de los mitos griegos y en particular de Dionisios, llega lejos: "[...] lo que llamamos 'cultura', considera, depende en todas sus formas de un mito con menoscabo de la solidaridad social [...]" (OTTO, 1997, p. 112). Otto se explica este mito por "[...] la experiencia de una presencia sublime, cuyo testimonio más poderoso serían las prácticas de culto [...]" (1997, p. 29). El fenómeno primigenio del mito crea desde la comunidad y la cultura hasta los objetos de pensamiento, la experiencia, el sentimiento y la voluntad, siempre según Otto (1997). El mito, inseparable del culto, hace de éste un instrumento que es justamente de "elevación", por así decirlo, mediante procedimientos que no siempre son gratuitos: se da poder con la esperanza de que quien lo tiene sepa a su vez, llegado el momento, "repartirlo". A juicio de Otto, esta llega a ser una visión utilitaria del mito, al ver en el culto un deseo de ganancia por parte de quienes lo hacen, esperando algo del dios, un efecto benéfico (OTTO, 1997). ¿Se esperaría del hombre - las más de las veces varón, en América Latina - mitificado y objeto de culto el otorgamiento de algún favor? ¿Sucede que, siguiendo a Otto, pudiera ocurrirles a los hombres el "[...] rivalizar por obtener los favores de aquello tan grande que les hace estremecerse [...]" (OTTO, 1997, p. 18), aunque el autor considere que no es demasiado grave confundir a los benefactores haciéndolos susceptibles de "halagos, promesas y favores"? A fin de cuentas, "ofrendar" no es forzosamente utilitario: en la cercanía con dios, es también una "[...] disposición de ánimo cuya grandeza solo tiene parangón en las obras del arte más noble" (OTTO, 1997, p. 23). La proximidad con la divinidad, con lo excelso, no es para Otto "[...] óbice para que a la divinidad se le ofrezca en el culto algo que la regocije y que posea cierto valor para ella, y que a ello se le una el natural deseo de recibir los parabienes de su benevolencia (OTTO, 1997, p. 21). A mayor poder y mayor engrandecimiento mayores serían las posibilidades de obtener favores, por lo que mitificar interesaría aunque el mitificado parasite y explote. El "providencialismo" es dado por cierto en la psicología como propio del pensamiento mítico - del niño de dos a siete u ocho años; es posible asociar mitificación y espera de la "providencia" (¿Ojalá que llueva café en el campo, según el campesino dominicano del conuco?).

En una visión como la de Otto el culto sirve para engrandecer: "[...] el culto, más que ninguna otra creación, considera este autor, da fe de un encuentro con lo sobrehumano[...]" (OTTO, 1997, p. 27). Así, "[...]la creación del culto posee la singularidad de que carece de distancia. Está tan ligado a un imperio(so) sentido de cercanía con lo sobrehumano que el hombre se ve arrastrado con su propia ser al acto de la configuración creadora [...]" (OTTO, 1997 , p. 27). El culto es la presencia de lo divino y "[...] presupone un mito al menos latente: la grandeza que está llamado a honrar ha de existir previamente: un ser sagrado, es decir, 
un todo transido de realidad[...]" (OTTO, 1997, p. 19). Al final, el mito y sus orígenes pueden ser olvidados y el mito es sobre todo "[...] una fantasía suscitada por medio de las prácticas del culto [...]" (OTTO, 1997, p. 19). Retomando a Ramos, podría decirse entonces que una sociedad que quiere ser mítica será en todo caso ceremoniosa, para permitir que se abra paso entre tal o cual el sentimiento de superioridad creado por el colectivo mediante el reiterado engrandecimiento y los "mimos". Es este engrandecimiento el que puede dar la sensación de algo sobrenatural y por encima de los hombres. Otto reitera en lo grandioso:

\begin{abstract}
Si, por lo tanto, dice, el culto no es acción pragmática, sino imponentes creaciones emanadas del hálito de la divinidad manifestada, y los mitos no son fábulas, sino testigos de ese mismo encuentro con lo excelso; si se acepta que es necesario tomar conciencia de los fenómenos primigenios y hacer justicia a las grandes realidades, de nada nos vale entonces el estudio de la psicología y la lógica, de las que hasta ahora todo se esperaba (OTTO, 1997, p. 41).
\end{abstract}

El mismo culto, "[...] como un todo pertenece a la categoría de las creaciones monumentales del espíritu humano[...]" y por ende a "lo excelso" (OTTO, 1997, p. 21). Las "[... viviendas de lo divino" son "[...] espejo y reflejo nacido de un espíritu obligado a crear cuando es tocado por el brillo de su grandeza[...]" (OTTO, 1997, p. 21). Así, "[...]el más excelso de estos grandes lenguajes es el culto [...]" (OTTO, 1997, p. 22).

\title{
5 CONCLUSION
}

El mito llega a plantearse a partir del siglo XX no solo como alternativa al racionalismo, sino inclusive como algo superior, por ejemplo en el "macondismo". No es más que una imagen en espejo y en cierto modo dirigida no a la idea de lo que es el otro, sino a la creencia de lo que es (lo que se cree que es): pese a que esta "superioridad" está dirigida contra lo europeo, lo sorprendente, según hemos visto, es el peso que tiene en América Latina y en perspectiva a la vez comparada e interdisciplinaria la semejanza con la mitología en toda una corriente de un pensamiento como el alemán, que tendió toda suerte de puentes con la mitológica Grecia antigua.

Hay en los fenómenos descritos algo que sorprende: lo que está naturalizado, al dársele un ropaje natural y poder al sentimiento de superioridad, es la creencia religiosa en el mismo poder, "sobrecargado" con el mito latente sobre "la vida misma" que "es" y "se manifiesta". Este poder se sigue encontrando revestido de dones que parecen sobrenaturales, aunque no sea sino la forma de lo creado por la colectividad al rendir culto. En la medida en que opera con creencias y rechaza los conceptos, que para Durkheim son un producto colectivo, los mitos no permiten tener una idea de la estructura de sociedad que ayude a transformarla a fondo.

Quedaría por saber si el "mito latente" no es el poder que hay en una sociedad que, como la actual, tiene con las imágenes los medios para darse un "brillo" muy particular. Si este nuevo poder se mostrara a la larga dañino, lo sería también el modo en que ha convertido en mitos desde Macondo hasta el Che Guevara. La "venganza" latinoa- 
mericana - "venganza de Moctezuma", diría la ironía mexicana- que habría consistido en revestir al poder de "alma" y "sensualidad", dados como parte de cierta naturaleza humana, habrían sido a fin de cuentas muy hábilmente recuperados por los medios de comunicación actuales.

\section{BIBLIOGRAFIA}

ADLER, Alfred. El sentido de la vida. México D.F: Editora Latinoamericana, 1956.

BLUMENBERG, Hans. El mito y el concepto de realidad. Barcelona: Herder, 2004.

DUCH, Lluis. Mito, interpretación y cultura. Barcelona: Herder, 2002.

DURKHEIM, Emile. Las formas elementales de la vida religiosa. México: Colofón, 2000.

DORON, Roland; PAROT, Francoise. Diccionario Akal de psicología. Madrid: Akal, 2008.

GADAMER, Hans-Georg. Mito y razón. Barcelona: Paidós, 1997.

GARCIA GUAL, Carlos. Introducción a la mitología griega. Madrid: Alianza, 2004.

LEENHART, Maurice. Do Kamo. La persona y el mito en el mundo melanesio. Barcelona: Paidós, 1997.

LEVI-STRAUSS, Claude Mito y significado. Madrid: Alianza, 2012.

LEVY-BRUHL, Lucien. El alma primitiva. Barcelona: Península, 1985.

OTTO, Walter F. Dionisio. Mito y culto. Madrid: Ediciones Siruela, 1997.

PAZ, Octavio. El ogro filantrópico. México: Joaquín Mortiz, 1990.

PEREYRA, Carlos. Breve Historia de América. México: Ed. Patria, 1982.

RAMOS, Samuel. El perfil del Hombre y la cultura en México. Madrid: Espasa Calpe, 2001.

ROUGEMONT, Denis. El amor y Occidente. México: Conaculta, 2001.

SCHAJOWICZ, Ludwig. Mito y existencia. Río Piedras: Editorial de la Universidad de Puerto Rico, 1990.

SCHAJOWICZ, Ludwig. De Winckelmann a Heidegger. Ensayos sobre el encuentro griego-alemán. Río Piedra: Editorial de la Universidad de Puerto Rico, 1986.

VERNANT, Jean-Pierre. Mito y pensamiento en la Grecia antigua. Ariel, Barcelona, 1973. 